\title{
Investigational Product and Clinical Trial Supplies Communication Record
}

National Cancer Institute

\section{Source}

National Cancer Institute. Investigational Product and Clinical T rial Supplies

Communication Record. NCI Thesaurus. Code C115565.

Documentation providing information regarding communications pertaining to the investigational product, and associated trial supplies. 